\title{
COVID-19-associated acute cerebral venous thrombosis: clinical, CT, MRI and EEG features
}

\author{
Fabian Roy-Gash ${ }^{1 *} \mathbb{D}$, Marine De Mesmay ${ }^{1}$, Jean-Michel Devys ${ }^{1}$, Hervé Vespignani ${ }^{2}$, Raphaël Blanc ${ }^{3}$ and \\ Nicolas Engrand ${ }^{1}$
}

Keywords: Cerebral venous thrombosis, Intracerebral hematoma, Electroencephalography, SARS-CoV-2, COVID-19, Pandemics, Diagnostic imaging

Dear editor,

Many recent COVID-19 series have reported arterial or venous thrombosis (stroke, pulmonary embolism, etc.) $[1,2]$. Here, we report a case of COVID-19 associated cerebral venous thrombosis (CVT) with dramatic evolution.

On April 3, 2020, a 63-year-old female presented to the emergency department because of aphasia and right hemiplegia. She had a 12-day history of fever, cough, and anosmia. Her husband was hospitalized in intensive care for confirmed COVID-19 acute respiratory distress syndrome (ARDS). Brain MRI showed a large left temporal brain hemorrhage and a suspicion of CVT confirmed on a venous brain $\mathrm{CT}$ scan and chest $\mathrm{CT}$ showed typical COVID-19 patchy ground-glass opacities in both lungs (Fig. 1).

The patient suddenly suffered a clinical status epilepticus and was administered i.v. lacosamide.

Laboratory results showed hyperfibrinogenemia $(7.2 \mathrm{~g} / \mathrm{L})$ and high ferritin levels $(1427 \mu \mathrm{g} / \mathrm{L})$.

The nasopharyngeal and bronchial samples were negative for SARS-CoV-2.

* Correspondence: froygash@for.paris

Address for reprint: Fondation Ophtalmologique Adolphe de Rothschild, 29 Rue Manin, 75019 Paris, France.

${ }^{1}$ Neuro-Intensive Care Unit, Fondation Ophtalmologique Adolphe de Rothschild, 29 rue Manin, 75019 Paris, France

Full list of author information is available at the end of the article
Most common causes of genetic thrombotic disorders and antiphospholipid antibody syndrome were excluded.

The patient was started on an intravenous curative dose of heparin anticoagulation.

Electroencephalograpy (EEG) showed background theta activity unreactive to nociceptive stimulus, with pseudo-periodic activity of a short period composed of slow di-phasic waves irradiating towards the anterior regions (Fig. 2). Although subtle status epilepticus could not be excluded, the aspect was not typical and other successive EEG traces would confirm this non-epileptic paroxystic pseudo-periodic pattern. The patient eventually underwent surgical intracranial hematoma evacuation followed by decompressive craniectomy.

On April 17th, brain CT scan revealed a new intracranial contralateral bleeding most likely following contralateral venous thrombosis despite being properly treated with intravenous heparin. Venous angiography showed persistent left thrombosis (Fig. 1). On April 25th, the patient was tested positive for SARS-CoV-2 plasmatic IgG and IgM (ELISA test).

On April 29th, the patient died following therapeutic limitation after ethical consultation group expertise.

Although both samples were negative for SARS-CoV2 , we considered the patient infected by it, given the initial symptomatology, the confirmed infection in one relative, the specific aspect of the thoracic CT scan [3], and the positive serology. Furthermore, in this case, the thrombotic event occurred 12 days after the first 


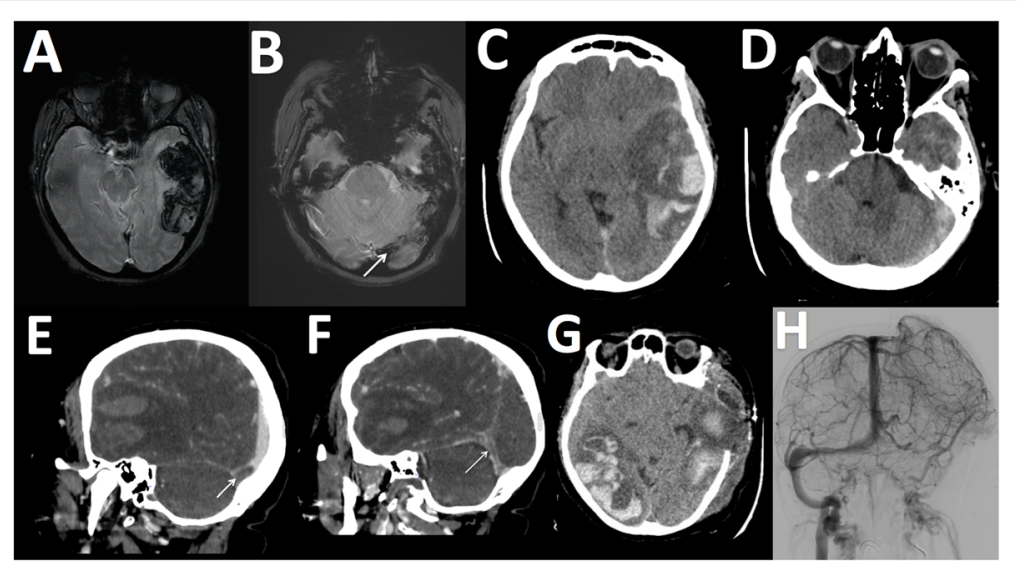

Fig. $1 \mathrm{MRI}$, venous CT scanner, and cerebral angiography at admission and day 14. MRI images (a, b) demonstrates voluminous left temporal hemorrhage with venous thrombosis (arrow). Venous CT scanner (c-f) confirms the existence of the extensive venous thrombosis. Located in the straight sinus and left lateral sinus (arrow). Day 14 CT scanner shows contro-lateral. Brain hemorrhage (g) and cerebral angiography shows persistent left thrombosis (h)

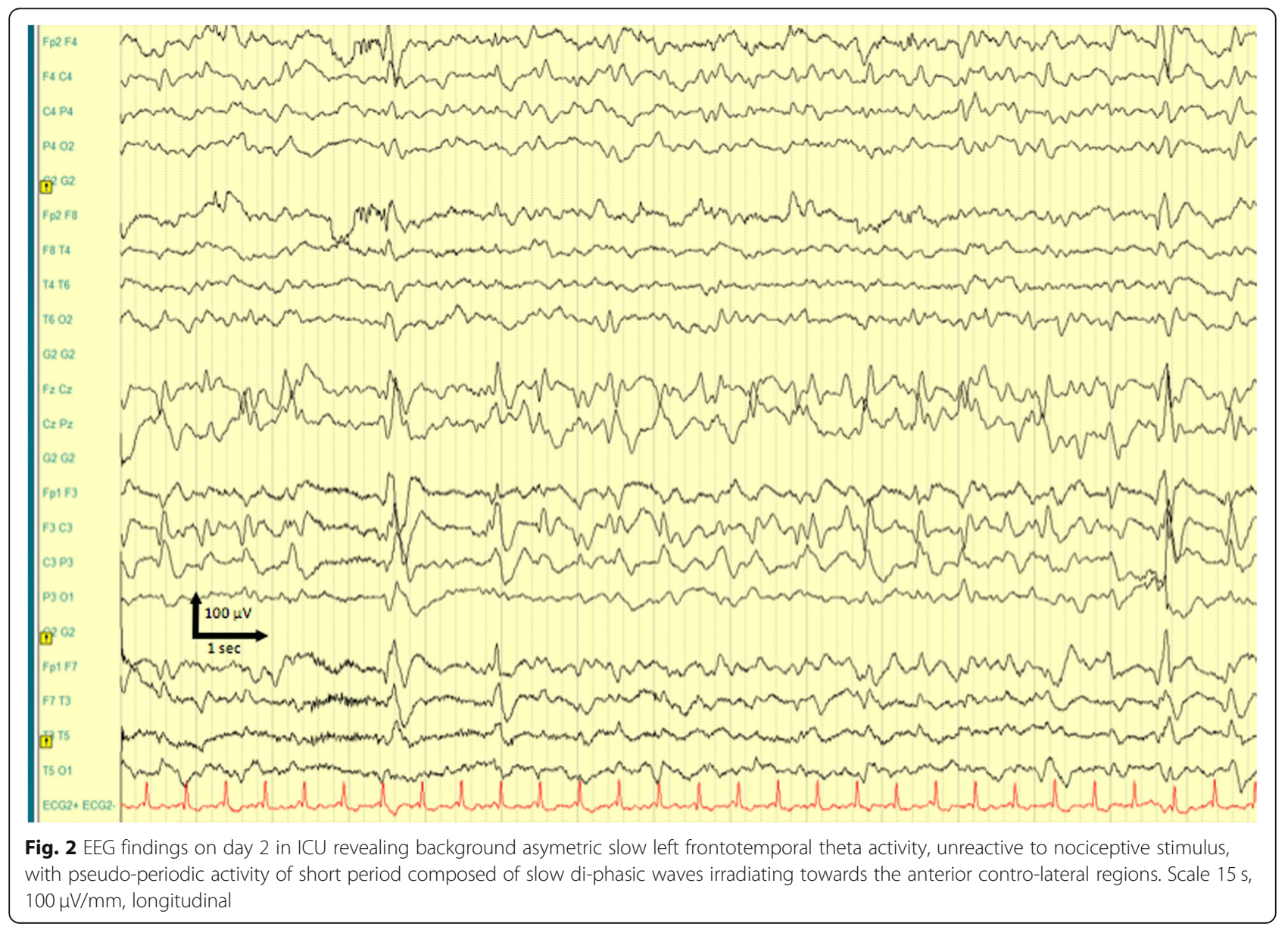


influenza-like symptoms, which corresponds to the most inflammatory period of COVID-19 $[4,5]$.

In addition to the left lesion temporal focus observed on the EEG, the background activity and paroxysmal activity describes atypical patterns, which can be mistaken with persistent epileptic activity. However, we believe it is compatible with newly described patterns of specific COVID-19 encephalopathy [6].

Overall, this case suggests that practitioners should be aware of the possibility of a CVT in this novel COVID-19 context, especially during the post-viral period.

\section{Abbreviations}

ARDS: Acute respiratory distress syndrome; COVID-19: Coronavirus disease 19; CVT: Cerebral venous thrombosis; EEG: Electroencephalography

\section{Acknowledgements}

The authors would like to thank Dr. Clementine Cholet, Dr. Vera Dinkelacker, and Dr. Basma Abdi for their precious help in retrieving data for this case report.

\section{Authors' contributions}

All the authors listed meet the authorship criteria. FRG and NE wrote the manuscript. MDM helped in obtaining important data. RB helped in obtaining relevant $\mathrm{CT}$ and MRI pictures. HV helped in understanding the EEG pattern. JMD and HV reviewed and edited the manuscript. The authors read and approved the final manuscript.

\section{Authors' information}

None.

\section{Funding}

None.

\section{Availability of data and materials}

All data analyzed in this report is available by simple request to the corresponding author.

\section{Ethics approval and consent to participate}

This study is only a retrospective report; therefore, no ethics approval was needed.

\section{Consent for publication}

Patient's family gave their written consent for publication.

\section{Competing interests}

H. Vespignani interprets electroencephalography patterns for his private firm Serenity Medical Service-Neurophy. All the other authors declare they have no competing interests.

\section{Author details}

${ }^{1}$ Neuro-Intensive Care Unit, Fondation Ophtalmologique Adolphe de Rothschild, 29 rue Manin, 75019 Paris, France. ${ }^{2}$ Serenity Medical Services-NeuroPhy, ICM-iPEPS, 47-85 Boulevard de l'Hôpital, 75013 Paris, France. ${ }^{3}$ Department of Interventional Neuro-Radiology, Fondation Rothschild, 29 rue Manin, 75019 Paris, France.

Received: 28 May 2020 Accepted: 1 July 2020

Published online: 11 July 2020

\section{References}

1. Shi S, Qin M, Shen B, et al: Association of cardiac injury with mortality in hospitalized patients with COVID-19 in Wuhan, China. JAMA Cardiol. 2020; doi:https://doi.org/10.1001/jamacardio.2020.0950.

2. Mao L, Jin $H$, Wang $M$, et al. Neurologic manifestations of hospitalized patients with coronavirus disease 2019 in Wuhan, China. JAMA Neurol. 2020. https://doi.org/10.1001/jamaneurol.2020.1127.
3. Fang $\mathrm{Y}$, Zhang $\mathrm{H}$, Xie J, et al: Sensitivity of chest CT for COVID-19: comparison to RT-PCR. Radiol. 2020;doi:https://doi.org/10.1148/radiol. 2020200432.

4. Siddiqi HK, Mehra MR: COVID-19 illness in native and immunosuppressed states: a clinical-therapeutic staging proposal. J Heart Lung Transplant. 2020; doi:https://doi.org/10.1016/j.healun.2020.03.012.

5. Tang N, Li D, Wang X, Sun Z. Abnormal coagulation parameters are associated with poor prognosis in patients with novel coronavirus pneumonia. J Thromb Haemost. 2020;18(4):844-7.

6. Vespignani H, Colas D, Lavin BS, et al. Report of EEG Finding on Critically III Patients with COVID-19 [published online ahead of print, 2020 Jun 13]. Ann Neurol. 2020; https://doi.org/10.1002/ana.25814.

\section{Publisher's Note}

Springer Nature remains neutral with regard to jurisdictional claims in published maps and institutional affiliations.

\section{Ready to submit your research? Choose BMC and benefit from:}

- fast, convenient online submission

- thorough peer review by experienced researchers in your field

- rapid publication on acceptance

- support for research data, including large and complex data types

- gold Open Access which fosters wider collaboration and increased citations

- maximum visibility for your research: over $100 \mathrm{M}$ website views per year

At $\mathrm{BMC}$, research is always in progress.

Learn more biomedcentral.com/submissions 